\title{
Dietary inclusion of ensiled avocado oil cake affects growth, nutrient digestion, and carcass characteristics of pigs
}

\author{
M.L. Seshoka ${ }^{1,2}$, P.J. Fourie ${ }^{2}$, A.T. Kanengoni ${ }^{3}$, I.M.M. Malebana ${ }^{1}$, \\ R.S. Thomas ${ }^{1}$ \& B.D. Nkosi $i^{\#, 1,3}$ \\ ${ }^{1}$ Division for Animal Nutrition: Animal Production Institute, P/Bag x 2, Irene, 0062, South Africa \\ ${ }^{2}$ Central University of Technology, Free State (CUT), Private Bag X20539, Bloemfontein, 9300, South Africa, \\ 3 Johannesburg Zoo, Private Bag X13, Parkview, 2122 \\ ${ }^{3}$ Centre for Sustainable Agriculture, University of the Free State, P.O. Box 339, Bloemfontein, 9300, South Africa
}

(Submitted 20 August 2019; Accepted 23 July 2020; Published 15 December 2020)

\author{
Copyright resides with the authors in terms of the Creative Commons Attribution 4.0 South African Licence. \\ See: http://creativecommons.org/licenses/by/4.0/za \\ Condition of use: The user may copy, distribute, transmit and adapt the work, but must recognise the authors and the South African \\ Journal of Animal Science.
}

\begin{abstract}
In this experiment, the effects were evaluated of various dietary inclusion levels of avocado oil cake (AOC) silage on growth performance, nutrient digestibility, and carcass characteristics in pigs. A mixture of $70 \%$ AOC, $25 \%$ wheat bran, and $5 \%$ sugarcane molasses was ensiled in $200 \mathrm{~L}$ drums for 90 days. It was then incorporated at $0 \%, 3 \%$ and $5 \%$ in the experimental diets. Twenty-seven Large White cross Landrace (LW $\times$ LR) weaner pigs, with an average live weight of $22 \mathrm{~kg}$, were stratified by weight and randomly allocated to the three experimental diets (9 pigs/diet). Pigs were weighed individually each week throughout the trial. Daily feed intake, average daily gain (ADG) and feed conversion rates (FCRs) were recorded. A nutrient digestibility study was carried out on completion of the growth trial. At the end of the experiment, pigs were fasted for twelve hours and weighed to determine the final weight. The pigs were then slaughtered, and carcass samples were collected and analysed. The growth performance of pigs was not affected by diet, irrespective of fibre levels in the AOC silage. However, the addition of $3 \%$ AOC silage improved the digestibility of fibre fractions. The weights of the cold carcass, chops, and backfat thickness were reduced with $A O C$ silage addition.
\end{abstract}

Keywords: energy, forages, inoculants, nutrients, silage, wastes

"Corresponding author: dnkosi@arc.agric.za

\section{Introduction}

Intensive pig production in South Africa is costly owing to the high prices of feed ingredients. Smallholder pig farmers therefore rely on non-conventional feed resources to sustain production (Lekule \& Kyvsgaard, 2003; Lemke \& Zarate, 2008). These resources are fibrous, which affects pig performance negatively, especially in growing pigs. Feeding high fibre diets to growing pigs was often associated with increased gut fill and gastrointestinal weight, which affected the growth performance negatively and lowered the dressing percentage (Carlson et al., 1999). This was attributed to the limited capacity for feed intake and hindgut fermentation of fibrous feed resources in young pigs.

To sustain pig production under smallholder farmers in South Africa, the use of alternative feed resources must be considered, such as avocado (Persea Americana) oil cake (AOC), a by-product of oil extraction from avocado fruits in South Africa. This by-product contains $518 \mathrm{~g}$ neutral detergent fibre (NDF), $393 \mathrm{~g}$ acid detergent fibre (ADF), $258 \mathrm{~g}$ acid detergent lignin (ADL), $38 \mathrm{~g}$ acid detergent insoluble nitrogen (ADIN) (Skenjana et al., 2006), and $119 \mathrm{~g} / \mathrm{kg}$ dry matter (DM) (Nkosi et al., 2020). Avocado oil cake contains $59 \mathrm{mg} / 100 \mathrm{~g}$ lysine, $40 \mathrm{mg} / 100 \mathrm{~g}$ threonine, and $29 \mathrm{mg} / 100 \mathrm{~g}$ methionine, making it a poor source of amino acids (Ortega, 2003).

Silage making reduces fibre fractions in forages owing to the activity of enzymes during fermentation (McDonald et al., 2010). Fermentation during silage production is a simple cost-effective and efficient way of improving the nutritional value of oilseed by-products (Duodu et al., 2018). Feeding pigs silage is a practice that has been carried out for years but is less common to emerging pig farmers in South Africa. This practice is limited owing to the high content of fibre in the feed, which affects pig growth performance negatively. For 
example, dietary inclusion of $500 \mathrm{~g}$ maize silage $/ \mathrm{kg}$ DM reduced the growth performance and feed conversion in fattening pigs (Scipioni \& Martelli, 2001). However, the advantages of feeding silage to pigs include better feed efficiency and physical activeness (Akerfeldt et al., 2018). In addition, Wustholz et al. (2017) fed pigs on diets that contained $20 \%$ to $50 \%$ lucerne silage and they consumed more fibre than those on the control diet without affecting weight gain.

The objective of the present study was to evaluate the effects of feeding AOC silage at various inclusion levels on the growth performance, nutrient digestion, and carcass characteristics of growing pigs.

\section{Materials and Methods}

The study was conducted at the Agricultural Research Council Institute in Irene, South Africa $\left(28{ }^{\circ}\right.$ $12^{\prime} 40$ 'E: $25^{\circ} 54^{\prime} 36 \mathrm{~S}$, altitude $1526 \mathrm{~m}$ ) about $15 \mathrm{~km}$ south of Pretoria. Batches of AOC were collected from Westfalia in Pietermaritzburg, South Africa, and brought to ARC-Irene for proximate analysis and silage production. The silage was produced by mixing $70 \%$ AOC, $25 \%$ wheat bran, and $5 \%$ sugarcane molasses by weight, ensiling this mixture in $210 \mathrm{~L}$ drums, and packing to a density of $820 \pm 29.8 \mathrm{~kg} / \mathrm{m}^{3}$. Ninety days after ensiling, the drums were opened, and silage samples were collected to determine nutrient composition. The diets, which contained 0\%, 3\%, and 5\% AOC silage, were formulated as shown in Table 1.

Table1 Formulation of experimental diets for weaner pigs containing avocado oil cake silage

\begin{tabular}{lccc}
\hline \multirow{2}{*}{ Ingredients, \% } & \multicolumn{3}{c}{ Treatments } \\
\cline { 2 - 4 } & 0\% AOC & $3 \%$ AOC & $5 \%$ AOC \\
\hline Maize meal & 73.97 & 73.02 & 71.02 \\
Wheat bran & 2.7 & 0.0 & 0.0 \\
Feed lime & 0.6 & 0.5 & 0.5 \\
Monocalcium phosphate & 1.85 & 2.00 & 2.00 \\
Soybean meal & 19.6 & 20.2 & 20.2 \\
Vitamin premix & 0.20 & 0.20 & 0.20 \\
Salt & 1.00 & 1.00 & 1.00 \\
Lysine & 0.08 & 0.08 & 0.08 \\
AOC silage & 0 & 3 & 5
\end{tabular}

1Per kilogram of diet: vitamin A: 6,500 IU, vitamin D3: 1,200 IU, vitamin E: $40 \mathrm{IU}$, vitamin K3: $2 \mathrm{mg}$, vitamin B1: $1.5 \mathrm{mg}$, vitamin $B_{2}: 4.5 \mathrm{mg}$, vitamin $B_{12}:, 0.03 \mathrm{mg}$, vitamin $B 6: 2.5 \mathrm{mg}$, niacin: $25 \mathrm{mg}$, calcium pantothenate: $12 \mathrm{mg}$, choline: 190.5 $\mathrm{mg}$, folic acid: $0.6 \mathrm{mg}$, biotin: $0.05 \mathrm{mg}$, manganese: $40 \mathrm{mg}$, zinc: $100 \mathrm{mg}$, copper: $125 \mathrm{mg}$, iodine: $1 \mathrm{mg}$, iron: $100 \mathrm{mg}$, selenium: $0.3 \mathrm{mg}$

AOC: avocado oil cake silage

This experiment was approved by the Animal Ethics Committee of ARC-Irene (approval no. APIECIS/027). Twenty-seven LW x LD pigs were used with an average initial live weight of $22 \mathrm{~kg}$. The pigs were stratified by live weight, and within strata were randomly allocated to the three experimental diets ( 9 pigs/treatment). Pigs were housed individually in pens $(1.96 \times 1 \mathrm{~m})$ and the feeders were checked and adjusted twice each day to ensure constant access to fresh feed, and to minimize wastage. Water was freely available through nipple drinkers. A period of 14 days was given for adaptation to the experimental conditions and the feeding trial took 60 days. Pigs were weighed individually at the start and then weekly until the end of the trial. The pigs were fed the diets ad libitum in the morning, allowing a $10 \%$ feed refusal. Daily feed intake was recoded and ADG and FCR were calculated.

A nutrient digestion study was done a week after completion of the growth study. Three $\mathrm{g} / \mathrm{kg}$ of chromic oxide was added to the daily ration of the pigs and used as an indigestible marker (Brandy et al., 2017). A three-day adaptation to chromic oxide was given, followed by five-day faecal collection using grabsampling methods. Faecal samples were collected once per day, weighed, and dried. The samples were then kept in $250 \mathrm{ml}$ plastic containers and chilled at $20^{\circ} \mathrm{C}$ for further analysis. Samples that were collected over the five-day period were pooled and stored for each pig.

At the end of the nutrient digestion experiment, pigs were fasted for twelve hours and weighed to determine the final weight. The pigs were then transported to the institute's abattoir for slaughter. Pig 
carcasses were processed according to the abattoir procedures, which included an ante-mortem inspection and rest before slaughter. The pigs were then stunned with an electrical stunner set at $220 \mathrm{~V}$ and $1.8 \mathrm{~A}$ with a current flow for 6 seconds and exsanguinated within 10 seconds of stunning. The hair was removed from the carcass and evisceration were done according to the abattoir's standard operating procedures. Warm carcass weight (WCW) was measured after dressing using an overhead scale. Dressing percentage (DP) was calculated by taking the WCW as percentage of live weight. The carcasses were then placed in a cold room and kept at an approximate temperature of $0{ }^{\circ} \mathrm{C}$ for 24 hours, after which cold carcass weights (CCW) were measured. After this, ultimate $\mathrm{pH}(\mathrm{pH}$ at 24 hours $(\mathrm{pH} 24)$ and temperature readings were taken from the Longissimus thoracis muscle (eye muscle) with a portable pH meter (EUTECH Instruments, Thermo Fisher Scientific Inc. Singapore) between the third and the fourth ribs, $60 \mathrm{~mm}$ from the midline. The $\mathrm{pH}$ meter had an automatic temperature compensator to adjust the $\mathrm{pH}$. Before use, the $\mathrm{pH}$ meter and electrode were calibrated at $\mathrm{pH} 4$ and $\mathrm{pH} 7$ and were recalibrated in $\mathrm{pH}$ buffers after every fourth reading. The head of each carcass was then removed at the atlanto-occipital joint and the tail at the junction of the third and fourth sacral vertebrae. The flare fat, kidneys, fat, glands, and remaining parts of the diaphragm were also removed. Carcasses were then split along the median plane from the remaining sacral vertebra to the cervical vertebra with a carcass splitting band saw. Backfat thickness was measured from the first rib (dorsal fat thickness at first rib) to the last rib (dorsal fat thickness at last rib) (Liu et al., 2015). Chops, loins, rib, legs, breast, and belly were taken from the left sides of the carcasses and measured.

Drip losses were measured from a chop that was cut from the Longissimus dorsi muscle between the fourth and eighth ribs. Samples of $80 \mathrm{~g}$ were trimmed and weighed. Each sample was placed in nylon mesh, sealed in a plastic bag for 24 hours at $2{ }^{\circ} \mathrm{C}$ and re-weighed, with the plastic bag also re-weighed to determine its empty weight. Drip loss was calculated by dividing the water loss of the meat by the original weight multiplied by 100 . Back fat was measured between the second and third ribs about $60 \mathrm{~mm}$ from the midline on the left carcass using a pair of Vanier clippers.

Dry matter of samples and diets was determined by drying the samples at $60^{\circ} \mathrm{C}$ until a constant mass was achieved and corrected for loss of volatiles using the equation of Weissbach and Strubelt (2008). After drying, the experimental feed samples were ground through a 1-mm screen Wiley mill (standard model 3, Arthur H. Thomas Co., Philadelphia, PA) to analyse crude protein (CP), gross energy (GE), fibre (aNDF, $A D F$ and $A D L$ ) and ether extract (EE). Organic matter, $C P$ and $E E$ were determined according to AOAC (2003). The aNDF, ADF and the ADL were determined according to the Van Soest et al. (1991). The aNDF was determined using heat stable $\alpha$-amylase (Sigma-Aldrich Co. Ltd., Gillingham, UK, no. A-1278) with sodium sulfite, and ADF was determined with Fibertec TM system equipment (Tecator Ltd., Thornbury, Bristol, UK). Separate samples were used for ADF and aNDF analysis and both included residual ash. The gross energy (GE) in diets and faeces was determined with a bomb calorimeter (MC-1000 modular calorimeter, Energy Instrumentation, 135 Knoppieslaagte, Centurion, South Africa).

The experiment was designed as a randomized complete block design with three blocks. Data on effects of treatment on the growth performance, nutrient digestion and carcass characteristics of pigs fed the AOC silage were analysed using Genstat (VSN International, Hemel Hempstead, UK). The linear model was:

$$
Y_{i j k}=\mu+t_{i}+b_{j}+e_{i j k}
$$

where: $Y_{i j k}=$ an observation from the kth pig in the jth block $\left(b_{j}\right)$ that was subject to the ith treatment $\left(t_{i}\right)$; $\mu=$ the overall mean; and

$\mathrm{e}_{\mathrm{ijk}}=$ experimental error.

Significance was declared at the $5 \%$ level of probability The least significant difference test was used to compare treatment means.

\section{Results and Discussion}

The diets had similar contents of gross energy and crude protein (Table 2). However, the addition of AOC silage reduced $(P<0.05)$ the DM content and increased their NDF content. This was expected since the AOC silage had high moisture and fibre contents (Table 3 ). 
Table 2 Nutritional composition of experimental diets for weaner pigs containing various levels of avocado oil cake silage $(n=3)$

\begin{tabular}{lccccc}
\hline Nutrient & \multicolumn{3}{c}{ Treatments } & SE & $P$-value \\
\cline { 2 - 4 } & $0 \%$ AOC & $3 \%$ AOC & $5 \%$ AOC & & \\
\hline Dry matter, g/kg & $884^{\mathrm{c}}$ & $786^{\mathrm{b}}$ & $747^{\mathrm{a}}$ & 1.24 & 0.001 \\
Ash, g/kg & $79^{\mathrm{a}}$ & $71^{\mathrm{c}}$ & $72^{\mathrm{b}}$ & 0.20 & 0.001 \\
Crude protein, g/kg & 126 & 125 & 125 & 0.30 & 0.252 \\
Ether extract, g/kg & 47 & 49 & 48 & 0.60 & 0.184 \\
Gross energy, MJ/kg DM & 21.8 & 21.9 & 21.8 & 0.03 & 0.243 \\
Alpha-amylase neutral detergent fibre, g/kg & $455^{\mathrm{b}}$ & $486^{\mathrm{a}}$ & $514^{\mathrm{a}}$ & 2.23 & 0.004 \\
Acid detergent fibre, g/kg & 257 & 263 & 288 & 5.31 & 0.232 \\
Acid detergent lignin, g/kg & 144 & 133 & 131 & 2.94 & 0.061 \\
\hline a,b,c & & & & &
\end{tabular}

Table 3 Nutritive values of avocado oil cake silage 90 days after ensiling $(n=3)$

\begin{tabular}{lc}
\hline Nutrient & Concentration \\
\hline Dry matter, g/kg & $379 \pm 6$. \\
Ash, g/kg & $24.7 \pm 0.5$ \\
Crude protein, g/kg & $136 \pm 3$. \\
Ether extract, g/kg & $51 \pm 1$. \\
Gross energy, MJ/kg DM & $20.6 \pm 2.5$ \\
Alpha-amylase neutral detergent fibre, g/kg & $238 \pm 4$. \\
Acid detergent fibre, g/kg & $148 \pm 3$. \\
Acid detergent lignin, g/kg & $75.5 \pm 3.7$ \\
\hline
\end{tabular}

The live weights of the pigs were similar at the beginning of the experiment. There were no differences $(P>0.05)$ in the final bodyweights, dry matter intake (DMI), ADG and FCR between treatments. Just (1984) reported high DMI in pigs fed a diet that contained high DM and low fibre compared with those fed on low DM and high fibre diets. Shimazawa et al. (2007) did not report differences in feed intake between pigs that were fed on a concentrate and those on total mixed potato silage. Ndindana et al. (2002) reported a decrease in ADG and feed intake in pigs with increasing dietary inclusion levels of maize cobs, but Kanengoni et al. (2014) did not observe this when maize cobs were ensiled. This means that ensiling improved the nutritive values of forages. This was consistent with the present study, since DMI and ADG in pigs were not affected by the inclusion levels of ensiled AOC. Kanengoni et al. (2014) reported a DMI of 1.4 $\mathrm{kg} / \mathrm{d}$ when feeding LW $\times$ LD pigs on diets containing ensiled maize cobs (200 g maize cob silage/ $\mathrm{kg}$ fresh matter), which is comparable with that of pigs in the present study. Data on the growth performance of pigs fed the experimental diets are shown in Table 4.

Under adequate feeding and management systems, growing pigs are expected to have an average daily gain of $640 \mathrm{~g} / \mathrm{d}$ (Payne, 1990). Pigs in the present study had ADG of $750 \mathrm{~g} / \mathrm{d}$, which is higher than that reported by Payne (1990). This could be attributed to the breed, since pig breeds react differently to diets. Dom and Ayalew (2009) fed pigs on diets that contained 50\% sweet potato silage and obtained ADG of 850 $\mathrm{g} / \mathrm{d}$, which was higher than that of pigs in the present study. An intake of $2320 \mathrm{~g} / \mathrm{d}$ is recommended for finishing pigs (National Research Council, 1998). Pigs in the present study had a daily intake that ranged between 1600 and $1900 \mathrm{~g} / \mathrm{d}$, which is lower than the reported value, because their bodyweight was lower than that reported by the NRC (1998) for finishing pigs. 
Table 4 Growth performance of weaner pigs fed diets that contained various levels of avocado silage $(n=9)$

\begin{tabular}{lccccc}
\hline Parameter & & Treatments & & SE & $P$-value \\
\cline { 2 - 4 } & 0\% AOC & 3\% AOC & 5\% AOC & & \\
\hline Initial bodyweight, $\mathrm{kg}$ & 22.5 & 23.3 & 23.9 & 1.47 & 0.793 \\
Final bodyweight, $\mathrm{kg}$ & 67.6 & 67.7 & 69.4 & 0.89 & 0.287 \\
Bodyweight gain, $\mathrm{kg}$ & 45.1 & 44.4 & 45.6 & 0.47 & 0.250 \\
Average daily feed intake, kg/day & 1.9 & 1.7 & 1.6 & 0.02 & 0.268 \\
Average daily gain, $\mathrm{kg} / \mathrm{day}$ & 0.75 & 0.74 & 0.76 & 0.04 & 0.589 \\
Feed conversion ratio, $\mathrm{kg} / \mathrm{kg}$ & 2.5 & 2.3 & 2.1 & 0.05 & 0.572 \\
& & & & & \\
\hline
\end{tabular}

AOC: avocado oil cake

The addition of maize silage to the diets of pigs was reported to increase dietary NDF more than maize meal, which affected the growth performance of the animals (Zanfi \& Spanghero, 2012). This was evident when AOC silage was added in the diets, and the NDF was increased (Table 4). However, when growing pigs are fed ad libitum, dietary energy content controls feed intake, and differences in fibre content should not affect DM intake, provided that the feed bulk and palatability are acceptable (Coffey et al., 1982). The diets of the present study had differences in NDF contents, but were iso-energetic (Table 4), hence the daily intake was not affected, which corroborates the findings of Len et al. (2008), who observed no differences in daily intake when diets had similar energy content. Importantly, the inclusion of AOC silage in pig diets resulted in similar growth performances to those that were fed the control diet. Campbell \& Taverner (1986) reported low feed intake in diets that contained a high level of fibre (120 g ADF/kg DM) compared with those with low fibre (62 $\mathrm{g} \mathrm{ADF} / \mathrm{kg} \mathrm{DM}$ ), but the energy contents of the diets were not similar. The reduced growth rate and poor feed efficiency in pigs fed high fibre diets might be related to increased energy requirements for body maintenance at the expense of growth (Agyekum et al., 2015).

The digestibility of DM and CP was improved $(P<0.05)$ in pigs fed the control diets compared with those that contained AOC. Several studies reported a trend towards a reduction in digestibility with increasing fibre content (for example Galassi et al., 2010), which was consistent with the present study. However, the improved digestibility of DM and CP in the control diet did not translate to improved growth performance in pigs fed the control (Table 3). Barrera et al. (2004) insisted that improved nutrient digestibility did not always translate to an improvement in pig performance, which was consistent with the present study. High fibre diets decrease energy and nutrient utilization in pigs owing to lack of the enzymes to break down fibre and are known to increase intestinal weight (Agyekum et al., 2015). In contrast, Souffrant (2001) concluded that the effect of dietary fibre on digestibility was inconstant, owing to the high variability in the physio/chemical characteristics of the diet. The digestibility of the fibre fractions in pigs was improved $(P$ $<0.05$ ) with the diet that contained $3 \%$ AOC silage compared with other diets. Data for the nutrient digestibility of the experimental diets are shown in Table 5.

Table 5 Nutrient digestion by weaner pigs fed diets containing various levels of avocado oil cake silage $(\mathrm{n}=$ 9)

\begin{tabular}{|c|c|c|c|c|c|}
\hline \multirow[t]{2}{*}{ Nutrient } & \multicolumn{3}{|c|}{ Treatments } & \multirow{2}{*}{ SE } & \multirow{2}{*}{$P$-value } \\
\hline & $0 \% \mathrm{AOC}$ & $3 \% \mathrm{AOC}$ & $5 \% \mathrm{AOC}$ & & \\
\hline Dry matter & $83.3^{\mathrm{a}}$ & $77.7^{\mathrm{b}}$ & $76.9^{\mathrm{b}}$ & 0.93 & $<0.001$ \\
\hline Crude protein & $82.4^{\mathrm{a}}$ & $71.1^{\mathrm{b}}$ & $74.9^{b}$ & 0.36 & $<0.001$ \\
\hline Ether extract & 76.4 & 76.4 & 75.7 & 0.77 & 0.206 \\
\hline Alpha-amylase neutral detergent fibre & $70.2^{\mathrm{b}}$ & $73.6^{\mathrm{a}}$ & $70.9^{\mathrm{b}}$ & 0.44 & $<0.001$ \\
\hline Acid detergent fibre & $70.9^{c}$ & $74.6^{\mathrm{a}}$ & $72.7^{b}$ & 0.16 & $<0.001$ \\
\hline Acid detergent lignin & $68.1^{c}$ & $73.5^{\mathrm{a}}$ & $60.8^{b}$ & 0.40 & $<0.001$ \\
\hline
\end{tabular}

${ }^{a, b, c}$ Means with a common superscript were not different at a probability level of $5 \%$; AOC: avocado oil cake silage 
Warm carcass weight was not affected $(P>0.05)$ by treatments, but pigs in the control had heavier $(P$ $<0.05)$ carcasses compared with those from AOC silage. It is well documented that pigs fed on high fibre diets are heavier in relation to those fed on low fibre diets (for example Thacker, 2006), probably because of the increased weight of their visceral organs and the gastro-intestinal tract (Len et al., 2008). Since the AOC silage diets contained high fibre compared with the control, it was expected that pigs fed these diets would have carcasses with a low DP. However, the DP was not affected $(P>0.05)$ by treatment $($ Table 5$)$. This is inconsistent with Thacker (2006), who reported a decrease in DP and the loin lean as the inclusion level of wheat dried distillers' grains was increased without any adverse effect on growth performance. Data from the effects of treatments on the carcass characteristics are shown in Table 6.

Table 6 Carcass characteristics of pigs fed diets differing in the level of avocado oil cake silage $(n=9)$

\begin{tabular}{|c|c|c|c|c|c|}
\hline \multirow[t]{2}{*}{ Carcass trait } & \multicolumn{3}{|c|}{ Treatments } & \multirow{2}{*}{ SE } & \multirow{2}{*}{$P$-value } \\
\hline & $0 \% \mathrm{AOC}$ & $3 \% \mathrm{AOC}$ & $5 \% \mathrm{AOC}$ & & \\
\hline Warm carcass weight, kg & 51.4 & 50.9 & 50.6 & 2.72 & 0.130 \\
\hline Cold carcass weight, $\mathrm{kg}$ & $50.4^{\mathrm{a}}$ & $48.8^{b}$ & $48.6^{b}$ & 9.33 & 0.003 \\
\hline Dressing percentage $\%$ & 74.6 & 75.2 & 72.9 & 4.07 & 0.174 \\
\hline Warm muscle $\mathrm{pH}_{\mathrm{i}}$ & 6.6 & 6.7 & 6.5 & 0.10 & 0.543 \\
\hline Cold muscle $\mathrm{pH}_{\mathrm{u}}$ & 6.4 & 6.4 & 6.4 & 0.28 & 0.970 \\
\hline Back-fat thickness, mm & $12.7^{\mathrm{a}}$ & $9.2^{b}$ & $9.8^{b}$ & 1.43 & 0.005 \\
\hline Chop, kg & $54.0^{\mathrm{a}}$ & $47.8^{b}$ & $49.2^{b}$ & 1.90 & 0.011 \\
\hline Loin, kg & 6.1 & 5.9 & 5.9 & 0.18 & 0.914 \\
\hline Rib, kg & 6.0 & 6.3 & 6.3 & 0.17 & 0.456 \\
\hline Leg, kg & 6.4 & 6.3 & 6.4 & 0.12 & 0.627 \\
\hline Breast, kg & 1.8 & 1.8 & 1.8 & 0.01 & 0.814 \\
\hline Belly, kg & 1.3 & 1.3 & 1.3 & 0.01 & 0.548 \\
\hline Drip loss \% & 2.0 & 2.2 & 2.2 & 0.02 & 0.712 \\
\hline
\end{tabular}

${ }^{a, b, c}$ Means with a common superscript were not different at a probability level of $5 \%$ AOC: avocado oil cake silage

Back-fat thickness is usually affected by dietary composition (Hernandez-Lopez et al., 2016). Galassi et al. (2016) reported reduced back-fat deposition in the carcasses of pigs with the addition of maize silage, which was consistent with the present study. In contrast, Moset et al. (2015) fed pigs on diets containing citrus pulp silage and observed a decreased carcass yield, whereas the back-fat of the carcasses increased. In addition, Bocian et al. (2017) fed fattening pigs with a diet that contained $14 \mathrm{~kg}$ steamed potato silage and reported that pigs fed the control diet had thinner back-fat, higher loin muscle and higher meatiness than those fed diets that contained silage. The various effects of silage diets on the back-fat thickness in pig carcasses might be attributed to the differences in the dietary compositions between the present study and those of the literature. High dietary energy leads to increased back-fat thickness (Apple et al., 2004). However, the energy contents of the diets in the present study were the same. Thus, the reduced back-fat thickness with the AOC silage diets could be related to balanced amino acids, which are responsible for protein synthesis, and the shortage of these nutrients could result in greater fat deposition and lower lean meat deposition in pigs fed silage (Zanfi et al., 2014). Feeding LW x LD pigs diets containing $200 \mathrm{~g}$ maize cob silage/kg resulted in carcass back-fat thickness of $10 \mathrm{~mm}$ (Kanengoni et al., 2014), which is comparable with that of the present study. The back-fat thickness was higher $(P<0.05)$ in the carcasses of pigs from the control diet compared with those on AOC silage (Table 6).

Drip loss in pork is affected by complex factors, which include the rate of $\mathrm{pH}$ decline and ultimate $\mathrm{pH}$ (Kanengoni et al., 2014). The ultimate $\mathrm{pH}$ of the pig carcasses in this study was similar $(P>0.05)$ across treatments, hence the percentage of drip loss was not affected.

\section{Conclusion}


The growth performance of pigs was not affected by inclusion of up to $5 \% \mathrm{AOC}$ silage, irrespective of the level of fibre. The weights of the cold carcass and chops were reduced with AOC silage addition. However, AOC silage reduced the back-fat thickness of the pig carcasses, which is good for human consumption. The use of $A O C$ in the form of silage could be adopted by smallholder pig farmers to resolve feed shortages and reduce environmental pollution. Further research is needed to determine the amino acid profile and minerals in AOC.

\section{Acknowledgements}

The authors wish to thank the National Research Foundation (Grant No. 108992) for funding this project. Ms Cynthia Ngwane is acknowledged for her assistance with statistical design and analysis.

\section{Authors' contributions}

BDN, PJF and MLS were in charge of project design and writing of the manuscript. BDN, PJF, MLS and IMMM were in charge of project implementation. All co-authors participated in results, statistics, and interpretation of the study. We also confirm that this manuscript has been read and approved by all authors and that the order of authors listed in the manuscript has been approved by all of us.

\section{Conflict of Interest Declaration}

We wish to confirm that there is no known conflict of interest associated with the publication of this manuscript and there has been no significant financial support for this work that could have influenced its outcome.

\section{References}

Agyekum, A.K., Sands, J.S., Regassa, A., Kiarie, E., Weihrauch, D., Kim, W.K. \& Nyachoti, C.M., 2015. Effect of supplementing a fibrous diet with a xylanase and b-glucanase blend on growth performance, intestinal glucose uptake, and transport associated gene expression in growing pigs. J. Anim. Sci. 93, 3483-3493.

Akerfeldt, M.P., Nihlstrand, J., Neil, M., Lundeheim, N., Andersson, H.K. \& Wallenbeck, A., 2018. Chicory and red clover silage in diets to finishing pigs - influence on performance, time budgets and social interaction. Org. Agric. https://doi.org/10.1007/s13165-018-0216-z

AOAC, 2003. Official methods of analysis. 17th edition. Association of Official Analytical Chemists, Arlington, Virginia.

Apple, J.K., Maxwell, C.V., Brown, D.C., Friesen, K.G., Musser, R.E., Johnson, Z.B. \& Armstrong, T.A., 2004. Effects of dietary lysine and energy density on performance and carcass characteristics of finishing pigs fed ractopamine. J. Anim. Sci. 82, 3277-3287.

Barrera, M., Cervantes, M., Sauer, W., Araiza, A. \& Torrentera, N., 2004. lleal amino acid digestibility and performance of growing pigs fed wheat based diets supplemented with xylanase. J. Anim. Sci. 82, 1997-2003.

Bocian, M., Jankowiak, H., Kapelanski, W. \& Lenartowicz, M., 2017. The fattening results of pigs fed with a diet with the participation of silage from steamed potatoes. J. Central Euro. Agric. 18, 358-368.

Brandy, M.J., Patience, J.F., Lindemann, M.D., Stalder, K.J. \& Kerr, B. J., 2017. Disappearance and appearance of an indigestible marker in feces from growing pigs as affected by previous and current diet composition. J. Anim. Sci. Biotechnol. 8, 1-9.

Campbell, R.G. \& Taverner, M.L., 1986. The effects of dietary fibre, source of fat and dietary energy concentration on voluntary food intake and performance of growing pigs. Anim. Prod. 43, 327-333.

Capraro, D., Buccioni, A., Piasentier, E. \& Spanhero, M., 2017. Feeding finishing heavy pigs with corn silages: Effects on backfat fatty acid composition and ham weight losses during seasoning. Ital. J. Anim. Sci. 16, 588-592.

Carlson, D., Laerke, H.N., Poulsen, H.D. \& Jorgensen, H., 1999. Roughages for growing pigs, with emphasis on chemical composition, ingestion and faecal digestibility. Acta Agric. Scandinavica Section A: Anim. Sci. 49, 129136.

Coffey, M.T., Seerley, R.W., Funderburke, D.W. \& Campbell, H.C., 1982. Effects of heat increment and level of dietary energy and environmental temperature on the performance of growing-finishing swine. J. Anim. Sci. 54, 95-102.

Dom, M. \& Ayalew, W., 2009. Adaptation and testing of ensiling sweet potato tuber and vine for feeding pigs: on station growth performance on mixed silage diets. Papua New Guinea J. Res. Sci. Technol. 1, 86-96.

Duodu, C.P., Adjei-Boateng, D., Edziyie, R.E., Agbo, N.W., Owusu-Boateng, G., Larsen, B.K. \& Skov, P.V., 2018. Processing techniques of selected oilseed by-products of potential use in animal feed: effects on proximate nutrient composition, amino acid profile and antinutrients. Anim. Nutr. 4, 442-451.

Galassi, G., Colombini, S., Malagutti, L., Crovetto, G.M. \& Rapetti, L., 2010. Effects of high fibre and low protein diets on performance, digestibility, nitrogen excretion and ammonia emission in the heavy pig. Anim. Feed Sci. Technol. 134, $326-336$.

Galassi, G., Malagutti, L., Rapetti, L., Crovetto, G.M., Zanfi, C., Capraro, D. \& Spanghero, M., 2017. Digestibility, metabolic utilization and effects on growth and slaughter traits of diets containing whole plant maize silage in heavy pigs. Italian J. Anim. Sci. 16, 122-131.

Genstat, 2011. GenStat for Windows. 14th ed. VSN International, Hemel Hempstead, UK.

Hernandez-Lopez, S.H., Rodriguez-Carpena, J.G., Lemus-Flores, C., Grageola-Nunez, F. \& Estevez, M., 2016. Avocado waste for finishing pigs: Impact on muscle composition and oxidative stability during chilled storage. Meat Sci. 116, 186-192.

Just, A., 1984. Nutritional manipulation and interpretation of body composition differences in growing swine. J. Anim. Sci. $58,740-752$. 
Kanengoni, A.T., Chimonyo, M., Erlwanger, K.H., Ndimba, B.K. \& Dzama, K., 2014. Growth performance, blood metabolic responses, and carcass characteristics of grower and finisher South African Windsnyer-type indigenous and Large White $x$ Landrace crossbred pigs fed diets containing ensiled corncobs. J. Anim. Sci. 92, 5739-5748.

Lekule, F.P. \& Kyvsgaard, N.C., 2003. Improving pig husbandry in tropical resource-poor communities and its potential to reduce risk of porcine cysticercosis. Acta. Tropica. 87, 111-117.

Lemke, U. \& Zárate, A.V., 2008. Dynamics and developmental trends of smallholder pig production systems in North Vietnam. Agric. Syst. 96, 207-223.

Len, N.T., Lindberg, J.E. \& Ogle, B., 2008. Effect of dietary fibre level on the performance and carcass traits of Mong Cai F1 crossbred (Mong Cai x Yorkshire) and landrace x Yorkshire pigs. Asian-Aust. J. Anim. Sci. 21, $245-251$.

Liu, Y., Kong, X., Jiang, G., Tan, B., Deng, J., Yang, X., Li, F., Xiong, X. \& Yin, Y., 2015. Effects of dietary protein/energy ratio on growth performance, carcass trait, meat quality, and plasma metabolites in pigs of different genotypes. $J$. Anim. Sci. Biotechnol. 6, 36.

McDonald, P., Edwards, R.A., Greenhalgh, J.F.D., Morgan, C.A., Sinclair, L.A. \& Wilkinson, R.G., 2010. Animal nutrition. 7th edition. Pearson, Prentice Hall.

Moset, V., Piquer, O., Cervera, C., Fernandez, C.J., Hernandez, P. \& Cerisuelo, A., 2015. Ensiled citrus pulp as a byproduct feedstuff for finishing pigs: Nutritional value and effects on intestinal microflora and carcass quality. Spanish J. Agric. Res. 13, 1-12.

National Research Council (NRC), 1998. Nutrient requirements of swine. 10th ed. National Academy Press, Washington, DC.

Ndindana, W., Dzama, K. \& Ndiweni, P.N.B., 2002. Digestibility of high fibre diets and performance of growing Zimbabwean indigenous Mukota pigs and exotic Large White pigs fed maize based diets with graded levels of maize cobs. Anim. Feed Sci. Technol. 97, 199-208.

Nkosi, B.D., Meeske, R., Muya, M.C., Langa, T., Thomas, R.S., Malebana, I.M.M., Motiang, M.D. \& Van Niekerk, J.A., 2020. Microbial additives affect silage quality and ruminal dry matter degradability of avocado (Persia Americana) pulp silage. S. Afr. J. Anim. Sci. 49, 997-1007.

Ortega, T.M., 2003. Valor nutrimental de la pulpa fresca de aguacate Hass. In: Proceedings of the V World Avocado Congress, pp. 741-748.

Payne, W.J.A., 1990. An introduction to animal husbandry in the tropics. 4th edition. ELBS, Longman, Singapore. Pp. 627-683

Scipioni, R. \& Martelli, G., 2001. Consequences of the use of ensiled sugar beet-pulp in the diet of heavy pigs on performances, carcass characteristics and nitrogen balance: A review. Anim. Feed Sci. Technol. 90, 81-91.

Shimazawa, K., Honda, A., Takeno, T., Nishikawa, T. \& Ono, Y., 2007. Effect of potato mixed silage on growth performance and meat quality in finishing pigs. J. Anim. Sci. 78, 355-362.

Skenjana, A., Van Ryssen, J.B.J. \& Van Niekerk, W.A., 2006. In vitro digestibility and in situ degradability of avocado meal and macadamia waste products in sheep. S. Afr. J. Anim. Sci., 36, 78-81.

Souffrant, W.B., 2001. Effect of dietary fibre on ileal digestibility and endogenous nitrogen losses in the pig. Anim. Feed Sci. Technol. 90, 93-102.

Thacker, P.A., 2006. Nutrient digestibility, performance and carcass traits of growing-finishing pigs fed diets containing dried wheat distillers grains with solubles. Can. J. Anim. Sci. 86, 527- 529.

Weissbach, F.E. \& Strubelt, C., 2008. Correcting the dry matter content of maize silages as a substrate for biogas production. 63 Landtechnik 2, 82-83.

Wustholz, J., Carrasco, S., Berger, U., Sundrum, A. \& Bellof, G., 2017. Fattening and slaughtering performance of growing pigs consuming high levels of alfalfa silage (Medicago sativa) in organic pig production. Livest. Sci. 200, 46-52.

Zanfi, C. \& Spanhero, M., 2012. Digestibility of diets containing whole ear corn silage for heavy pigs. Livest. Sci. 145 , 287-291.

Zanfi, C., Colombini, S., Mason, F., Galassi, G., Rapetti, L., Malagutti, L., Crovetto, G.M. \& Spanghero, M., 2014. Digestibility and metabolic utilization of diets containing whole ear corn silage and their effects on growth and slaughter traits of heavy pigs. J. Anim. Sci. 92, 211-219. 